\title{
Heavy Metals in Bitter Gourd (Momordica charantia): Human Health Risk Assessment
}

\author{
Chee Kong Yap ${ }^{1 *}$, Aziran Yaacob ${ }^{1}$, Mohd Hafiz Ibrahim ${ }^{1}$, Rosimah Nulit ${ }^{1}$, Chee Seng Leow ${ }^{2}$ \\ ${ }^{1}$ Department of Biology, Faculty of Science, Universiti Putra Malaysia, 43400 UPM, Serdang, Selangor, \\ Malaysia \\ ${ }^{2}$ Humanology Sdn Bhd, 73-3 Amber Business Plaza, Jalan Jelawat 1, 56000 Kuala Lumpur, Malaysia
}

*Corresponding Author: Chee Kong Yap, Department of Biology, Faculty of Science, Universiti Putra Malaysia, 43400 UPM, Serdang, Selangor, Malaysia, Email: yapckong@hotmail.com; yapchee@upm.edu.my

\begin{abstract}
Momordica charantia (bitter gourd) were collected between May and December 2016 from Kg. Ara Kuda (Penang), Kuala Ketil (Kedah) and Sg. Rengat, Jerantut (Pahang) of Peninsular Malaysia. The metal concentrations ( $\mathrm{mg} / \mathrm{kg}$ dry weight) the edible fruity bitter gourd ranged from the three farming sites were8.00-16.1 for $\mathrm{Cu}, 46.0-118$ for $\mathrm{Fe}, 0.18-1.98$ for $\mathrm{Ni}, 0.79-1.46$ for $\mathrm{Pb}$ and 17.2-46.8 for $\mathrm{Zn}$. For the human health risk assessment via consumption of the bitter gourds, all the target hazard quotient values for $\mathrm{Fe}, \mathrm{Cu}, \mathrm{Ni}, \mathrm{Pb}$, and $\mathrm{Zn}$ were below 1.00. This indicated that there were no non-carcinogenic risks of $\mathrm{Fe}, \mathrm{Cu}$, $\mathrm{Ni}, \mathrm{Pb}$, and $\mathrm{Zn}$ via the consumption of bitter gourds from the three farming sites. However, it is still advisable that regular monitoring of heavy metals in the bitter gourds be conducted in order to check for possible toxicological risks of the bitter gourd consumption.
\end{abstract}

Keywords: Human health risk; Heavy metals; Fruity vegetable

\section{INTRODUCTION}

Oral consumption of metal-contaminated vegetables is of public concern because these bioaccumulated metals could create complicated health problems in the consumers (Khan et al. 2008). According to Ghous et al. (2015), Momordica charantia is a common fruity vegetable besides being used as a traditional medicine in South Asia. It is under the Family: Cucurbitaceae and commonly known as "bitter gourd". It is an annual and climber plant (Savsatli et al., 2016). Besides being a traditional medicinal plant, it is also a cultural plant. It can adapt well in many ecological conditions (Savsatli and Seyis, 2014), including many tropical and subtropical countries.

The bitter gourd is a potential source of enrichment of phenolic compounds (Islam et al., 2011; Gupta et al., 2011). Therefore, it has pharmacological values for many diseases. The fruits of bitter gourd contain laxative, antibilious, emetic and stomachic effects (Arya et al., 2011). Verma (2015) reported that all parts of the bitter gourd are beneficial for human and there is a distribution of elemental concentrations in different parts of the plant while Kosanovicet al. (2009) stated that bitter gourd is an important source of essential $\mathrm{Ca}$, $\mathrm{Mg}, \mathrm{Mn}, \mathrm{Cu}$ and $\mathrm{Zn}$.

The objectives of this study were to 1) assess the concentrations of $\mathrm{Fe}, \mathrm{Cu}, \mathrm{Ni}, \mathrm{Pb}$, and $\mathrm{Zn}$ in bitter gourd $M$. charantia from three farming areas of Peninsular Malaysia, and 2) assess the human health risks of the above five metals in the collected bitter gourds.

\section{MAterials AND Methods}

Bitter gourds $M$. charantia were collected between May and December 2016 from Kg Ara Kuda (Penang), Kuala Ketil (Kedah) and Sg. Rengat, Jerantut (Pahang) of Peninsular Malaysia (Table 1).

The samples were kept in clean polyethene bags and transported to the laboratory for further analyses. The identification of the bitter gourd was done based on Chin and Yap (1999), and Prohens and Nuez (2008a, 2008b). In the laboratory, the samples were washed with distilled water to remove soil particles. Later, they were cut into small pieces using a clean knife and were dried in an oven at $60^{\circ} \mathrm{C}$ for 72 hours days until a constant dry weight. 
For determination of heavy metals, all filtered samples were analysed by using a flame atomic absorption spectrophotometer (AAS) model
Thermo Scientific iCE 3000 series for $\mathrm{Cu}, \mathrm{Fe}$, $\mathrm{Ni}, \mathrm{Pb}$, and $\mathrm{Zn}$. All data obtained from the AAS were presented in $\mathrm{mg} / \mathrm{kg}$ dry weight basis.

Table1. Heavy metal concentrations (mg/kg dry weight) in the bitter gourd Momordica charantia (fruit) collected from three farms in Peninsular Malaysia.

\begin{tabular}{|c|c|c|c|c|c|c|c|c|c|}
\hline Site & & $\mathbf{C u}$ & $\mathbf{F e}$ & $\mathbf{N i}$ & $\mathbf{P b}$ & $\mathbf{Z n}$ & S.date & Source of irrigation & Reference \\
\hline $\begin{array}{l}\text { Sg Rengat, } \\
\text { Jerantut, } \\
\text { Pahang }\end{array}$ & Rengat & $\begin{array}{l}8.00 \\
(0.49)\end{array}$ & $\begin{array}{l}46.0 \\
(2.81)\end{array}$ & $\begin{array}{l}0.80 \\
(0.05)\end{array}$ & $\begin{array}{l}0.80 \\
(0.05)\end{array}$ & $\begin{array}{l}46.8 \\
(2.85)\end{array}$ & 12-May-16 & $\begin{array}{l}\text { Private farms, a river, } \\
\text { distance from highway, } \\
\text { surrounded by forest. }\end{array}$ & This study \\
\hline $\begin{array}{l}\text { Ara Kuda, } \\
\text { Penang }\end{array}$ & Ara & $\begin{array}{l}16.1 \\
(0.98)\end{array}$ & $\begin{array}{l}46.9 \\
(2.86)\end{array}$ & $\begin{array}{l}1.99 \\
(0.12)\end{array}$ & $\begin{array}{l}1.46 \\
(0.09)\end{array}$ & $\begin{array}{l}29.0 \\
(1.77)\end{array}$ & 12-Oct-16 & Tube well and stream & This study \\
\hline $\begin{array}{l}\text { Kuala Ketil, } \\
\text { Kedah }\end{array}$ & Ketil & $\begin{array}{l}14.5 \\
(0.89) \\
\end{array}$ & $\begin{array}{l}118 \\
(7.18)\end{array}$ & $\begin{array}{l}0.18 \\
(0.01)\end{array}$ & $\begin{array}{l}0.79 \\
(0.05)\end{array}$ & $\begin{array}{l}17.2 \\
(1.05)\end{array}$ & 8-Dec-16 & Tube well and stream & This study \\
\hline $\begin{array}{l}\text { Overall } \\
\text { Peninsular } \\
\text { Malaysia }\end{array}$ & 3 sites & \begin{tabular}{|l|}
$8.00-16.1$ \\
$(0.49-$ \\
$0.98)$
\end{tabular} & $\begin{array}{l}46.0-118 \\
(2.81- \\
7.18)\end{array}$ & $\begin{array}{l}0.18- \\
1.99 \\
(0.01- \\
0.12)\end{array}$ & $\begin{array}{l}0.79- \\
1.46 \\
(0.05- \\
0.09)\end{array}$ & $\begin{array}{l}17.2- \\
46.8 \\
(1.05- \\
2.85)\end{array}$ & & & \\
\hline
\end{tabular}

Note: Values in brackets are presented in wet weight basis ( $\mathrm{mg} / \mathrm{kg}$ wet weight).

For quality assurance and quality control, all the glassware used in this study were acid-washed to avoid external contamination. Two certified reference materials (CRM) were used to check for the analytical procedures of the present method. The CRMs analysed were
Lagarosiphon major N.60 and Peach Leaves (NIST 1547). The recoveries for the CRM Lagarosiphon major N.60 were 97.4, 120.2, $119 \%$ for $\mathrm{Zn}, \mathrm{Cu}$ and $\mathrm{Pb}$, respectively, while CRM Peach Leaves (NIST 1547) were 97.0 and $117 \%$ for $\mathrm{Ni}$ and $\mathrm{Fe}$, respectively (Table 2).

Table2. Comparison of metal concentrations $(\mathrm{mg} / \mathrm{kg}$ dry weight) between certified and measured values. The certified values are based on certified reference materials were Lagarosiphon major N.60 and Peach Leaves (NIST 1547).

\begin{tabular}{|l|l|l|l|}
\hline \multicolumn{3}{|c|}{ Lagarosiphon major N.60 } \\
\hline & Certified value & Measured value & Recovery (\%) \\
\hline $\mathrm{Cu}$ & $51.20 \pm 1.9$ & $61.54 \pm 1.4$ & 120.2 \\
\hline $\mathrm{Zn}$ & $313 \pm 8$ & $304.85 \pm 3.4$ & 97.4 \\
\hline $\mathrm{Pb}$ & $64 \pm 4.00$ & $76.3 \pm 2.40$ & 119 \\
\hline \multicolumn{5}{|l|}{ Peach Leaves (NIST 1547) } \\
\hline $\mathrm{Ni}$ & 0.689 & 0.81 & 117 \\
\hline $\mathrm{Fe}$ & 219.8 & 211 & 97.0 \\
\hline
\end{tabular}

For the human health risk assessment, the basis in dry weight was converted into wet weight by using a conversion factor of 0.061. The assessment included estimated daily intake (EDI) and target hazard quotient (THQ) values, as shown in the following formulas:

\section{$\mathrm{EDI}=(\mathrm{Mc} \times \mathrm{CR}) / \mathrm{BW}$}

where;

$\mathrm{Mc}=$ the metal concentration in biter gourds (mg/kg wet weight).

$\mathrm{CR}=$ the consumption rate of bitter gourds (345 g/day for adults and $232 \mathrm{~g} /$ day for children) and average body weight $(55.9 \mathrm{~kg}$ for adults and $32.7 \mathrm{~kg}$ for children) (Wang et al. 2005).

In this study, a non-carcinogenic risk assessment method was based on THQ, a ratio between the estimated dose of contaminant and the oral reference dose (RfD), below which there will not be any appreciable risk. The THQ was determined with a formula described by USEPA (2000):

$$
\mathrm{THQ}=\mathrm{EDI} / \mathrm{RfD}
$$

where;

$\mathrm{EDI}=$ estimated daily intake calculated previously;

$\mathrm{RfD}=$ the oral reference dose. The $\mathrm{RfD}(\mu \mathrm{g} / \mathrm{kg}$ wet weight/day) values used in this study were Fe: 700, Ni: 20.0, Cu: 40.0, and $\mathrm{Zn}: 300$, provided by the EPA's Integrated Risk Information System online database (IRIS 2000). This study used the RfD as $4.00 \mu \mathrm{g} / \mathrm{kg}$ wet weight/day as proposed by $\mathrm{FAO} / \mathrm{WHO}$ (2013) because RfD value for $\mathrm{Pb}$ was not available based on EPA's IRIS (2000). 
Table3. Values of estimated daily intake (EDI) of heavy metal concentrations in Momordica charantia collected from selected farms in Peninsular Malaysia.

\begin{tabular}{|l|l|l|l|l|l|l|l|l|l|l|l|}
\hline & \multicolumn{3}{|c|}{ Adults } & \multicolumn{5}{c|}{ Children } \\
\hline Consumption rate of vegetables (g/day) & \multicolumn{3}{|c|}{345} & \multicolumn{5}{c|}{32.7} \\
\hline Body weight (kg) & \multicolumn{3}{|c|}{55.9} & \multicolumn{3}{c|}{} \\
\hline & $\mathrm{Cu}$ & $\mathrm{Fe}$ & $\mathrm{Ni}$ & $\mathrm{Pb}$ & $\mathrm{Zn}$ & $\mathrm{Cu}$ & $\mathrm{Fe}$ & $\mathrm{Ni}$ & $\mathrm{Pb}$ & $\mathrm{Zn}$ \\
\hline Rengat & 3.01 & 17.32 & 0.30 & 0.30 & 17.62 & 4.82 & 27.72 & 0.48 & 0.48 & 28.20 \\
\hline Ara & 6.07 & 17.65 & 0.75 & 0.55 & 10.93 & 9.71 & 28.25 & 1.20 & 0.88 & 17.50 \\
\hline Ketil & 5.47 & 44.32 & 0.07 & 0.30 & 6.46 & 8.75 & 70.93 & 0.11 & 0.48 & 10.33 \\
\hline
\end{tabular}

Note: All metal data were concerted to wet weight basis using a conversion factor of 0.061 for the calculation of EDI.

Table4. Values of target hazard quotient (THQ) of heavy metal concentrations in Momordica charantia collected from selected farms in Peninsular Malaysia.

\begin{tabular}{|c|c|c|c|c|c|c|c|c|c|c|}
\hline & \multicolumn{4}{|c|}{ Adults } & \multicolumn{4}{c|}{ Children } \\
\hline $\mathrm{RfD}(\mu \mathrm{g} / \mathrm{kg}$ wet weight/day $)$ & 40.0 & 700 & 20.0 & 4.00 & 300 & 40.0 & 700 & 20.0 & 4.00 & 300 \\
\hline & $\mathrm{Cu}$ & $\mathrm{Fe}$ & $\mathrm{Ni}$ & $\mathrm{Pb}$ & $\mathrm{Zn}$ & $\mathrm{Cu}$ & $\mathrm{Fe}$ & $\mathrm{Ni}$ & $\mathrm{Pb}$ & $\mathrm{Zn}$ \\
\hline Rengat & 0.075 & 0.025 & 0.015 & 0.075 & 0.059 & 0.121 & 0.040 & 0.024 & 0.121 & 0.094 \\
\hline Ara & 0.152 & 0.025 & 0.037 & 0.137 & 0.036 & 0.243 & 0.040 & 0.060 & 0.220 & 0.058 \\
\hline Ketil & 0.137 & 0.063 & 0.003 & 0.074 & 0.022 & 0.219 & 0.101 & 0.005 & 0.119 & 0.034 \\
\hline
\end{tabular}

\section{RESULTS AND DISCUSSION}

\subsection{Concentrations of $\mathrm{Fe}, \mathrm{Cu}, \mathrm{Ni}, \mathrm{Pb}$, and $\mathrm{Zn}$}

The metal concentrations ( $\mathrm{mg} / \mathrm{kg}$ dry weight) in the bitter gourd collected from three farms are given in Table 1. The ranges of metal concentrations $(\mathrm{mg} / \mathrm{kg}$ dry weight (wet weight)) from the three sites were 8.00-16.1 (0.49-0.98) for $\mathrm{Cu}, 46.0-118$ (2.81-7.18) for $\mathrm{Fe}, 0.18$ $1.99(0.01-0.12)$ for Ni, 0.79-1.46 (0.05-0.09) for $\mathrm{Pb}$ and 17.2-46.8 (1.05-2.85) for $\mathrm{Zn}$.

Based on M. charantia collected from reclaimed tidal flat soils of Pearl River Estuary (China), Li et al. (2012) reported the $\mathrm{Cu}$ and $\mathrm{Zn}$ levels $(\mathrm{mg} / \mathrm{kg}$ wet weight) were 0.71 and 1.46 , respectively. Khan et al. (2013) reported the metal concentrations $(\mathrm{mg} / \mathrm{kg}$ wet weight) $M$. charantia from Swat District, northern Pakistan as 0.05 for $\mathrm{Cu}, 0.06$ for $\mathrm{Ni}$ and 0.09 for $\mathrm{Zn}$. Based on $M$. charantia grown around effluent sites of District Sargodha (Pakistan), Bibi et al. (2014) showed that the concentrations $(\mathrm{mg} / \mathrm{kg}$ dry weight) of $\mathrm{Ni}, \mathrm{Cu}$ and $\mathrm{Zn}$ in bitter gourds at both sites were 4.78-5.6 for $\mathrm{Ni}, 20.2-22.7$ for $\mathrm{Cu}$, and 52.3-61.8 for $\mathrm{Zn}$. Therefore, the intake of $M$. charantia was not safe for consumption in the sampling area.

\subsection{Health Risk Assessments}

The values of EDI and THQ of the five heavy metals in bitter gourd for adults and children are shown in Tables 3 and 4, respectively. All the THQ values for $\mathrm{Fe}, \mathrm{Cu}, \mathrm{Ni}, \mathrm{Pb}$, and $\mathrm{Zn}$ in both adults and children were found below 1.00. This indicates that there is no non-carcinogenic risk of $\mathrm{Cu}, \mathrm{Fe}, \mathrm{Ni}, \mathrm{Pb}$, and $\mathrm{Zn}$ via the consumption of the bitter gourd from the three farms. In general, the THQ values of heavy metals in children are higher than those in adults.

Zhang et al. (2017) reported that THQ values heavy metals were greater than one for adolescents in Kunming City (China), indicating non-carcinogenic risk of heavy metals to the adolescents. Islam et al. (2016) reported that THQs for $\mathrm{Cu}$ and $\mathrm{Zn}$ were below 1based on vegetables in Bogra District. This indicated that consumers would not experience significant health hazards of metals via ingestion of the vegetable. Khan et al. (2017) reported the concentrations of $\mathrm{Mo}, \mathrm{As}, \mathrm{Mn}, \mathrm{Ni}$ and $\mathrm{Zn}$ were higher than the maximum permissible limits in the bitter gourd irrigated with domestic wastewater. Unni et al. (1992) studied the effect of $\mathrm{Pb}$ on germination, growth, chlorophyll $\mathrm{a}, \mathrm{b}$ and total chlorophyll contents in M. charantia in a hydroponic system. They found that chlorophyll content is useful in vivo indicator of heavy metal toxicity for calculating the upper critical tissue concentrations. Ghous et al. (2015) determined the levels of antioxidant, metal chelating and antiglycation activities of aqueous extracts of $M$. charantia fruit flesh and fruit pulp fractions.

\section{Conclusion}

Based on the THQ values for $\mathrm{Cu}, \mathrm{Fe}, \mathrm{Ni}, \mathrm{Pb}$, and $\mathrm{Zn}$ in both adult and children, there were no non-carcinogenic risks of the five metals through the consumption of bitter gourds from 
the three farms. However, there is a need for regular monitoring of heavy metals in order to check for possible contamination of bitter gourd.

\section{ACKNOWLEDGEMENT}

The authors wish to acknowledge the partial financial support provided through the Fundamental Research Grant Scheme (FRGS), No. Project: 02-10-10-954FR and vote no.: 5524953, by Ministry of Higher Education, Malaysia.

\section{REFERENCES}

[1] Arya, V, Bhardwaj, A. and Sharma, V. 2011. Pharmacology of some antioxidant plants from district Kangrahimachal Pradesh a review. Int. J. Curr. Pharmaceut. Res.3(2): 26-31.

[2] Bibi, Z., Khan, Z.I., Ahmad, K., Ashraf, M., Hussain, A.and Akram, N.A. 2014. Vegetables as a potential source of metals and metalloids for human nutrition: A case study of Momordica charantia grown in soil irrigated with domestic sewage water in Sargodha, Pakistan. Pakistan J. Zool. 46(3):633-641.

[3] Chin, H.F. and Yap, E.E. 1999. Malaysian vegetables in colour: A complete guide. Kuala Lumpur: Tropical Press.

[4] FAO/WHO. 2013. Guidelines for the Safe Use of Wastewater and food stuff; Volume 2: No1 14, pp 988. Wastewater Use in Agriculture, World Health Organization, Geneva.

[5] Ghous, T., Aziz, N., Mehmood, Z. andAndleeb, S.2015. Comparative study of antioxidant, metal chelating and antiglycation activities of Momordica charantia flesh and pulp fractions. Pakistan J. Pharmaceut. Sci.28(4):1217-1223.

[6] Gupta, M., Sharma, S., Gautam, A.K. andBhadauria, R. 2011. Momordica charantia Linn. (Karela): nature's silent healer. Int. J. Pharmaceut. Sci. Rev. Res.11(1): 32-37.

[7] IRIS (Integrated Risk Information System) (2000) Supplementary Guidance for Conducting Health Risk Assessment of Chemical Mixtures. US Environmental Protection Agency. http://cfpub.epa.gov/ ncea/ $\mathrm{cfm} /$ recordisplay.cfm?deid=22567\#Download (accessed 27.05.15).

[8] Islam, S., Jalaluddin, M. andHettiarachchy, N.S. 2011. Bioactive compounds of bitter melon genotypes (Momordica charantia L.) in relation to their physiological functions. Func. Foods Heals Disease 2:61-74.

[9] Islam, M.S., Ahmed, M.K., and Habibullah-AlMamun, M. 2016. Apportionment of heavy metals in soil and vegetables and associated health risks assessment. Stochastic Environ. Res. Risk Assess. 30(1):365-377.

[10] Khan, Z.I., Ahmad, K., Parveen, R., Bashir, H. and Mehmood, N. 2017. High metal accumulation in bitter gourd irrigated with sewage water can cause health hazards. Fresenius Environ. Bull. 26(7):4332-4337.

[11] Khan, K., Lu, Y., Khan, H., Ishtiaq, M., Khan, S., Waqas, M., Wei, L. and Wang, T. 2013. Heavy metals in agricultural soils and crops and their health risks in Swat District, northern Pakistan. Food Chem.Toxicol. 58:449-458.

[12] Khan, S., Cao, Q., Zheng, Y.M., Huang, Y.Z. and Zhu, Y.G. 2008. Health risks of heavy metals in contaminated soils and food crops irrigated with wastewater in Beijing, China. Environ. Pollut. 152(3):686-692.

[13] Kosanovic, M., Hasan, M.Y., Petroianu, G., Marzouqi, A., Abdularhman, O. andAdem, A. 2009. Assessment of essential and toxic mineral elements in bitter gourd (Momorilca charantia) Fruit. Int. J. Food Propert. 12: 766-773.

[14] Li, Q., Chen, Y., Fu, H., Cui, Z., Shi, L., Wang, L. and Liu, X. 2012. Health risk of heavy metals in food crops grown on reclaimed tidal flat soil in the Pearl River Estuary, China. J. Hazard. Mater. 227-228:148-154.

[15] Prohens, J. and Nuez, F. 2008a. Vegetables I: Asteraceae, Brassicaceae, Chenopodicaceae, and Cucurbitaceae. New York: Springer.

[16] Prohens, J. and Nuez, F. 2008b. Vegetables II: Fabaceae, Liliaceae, Solanaceae, and Umbelliferae. New York: Springer.

[17] Savsatli, Y. and Seyis F. 2014. Effects of different planting frequency to some agricultural traits of bitter melon (Momordica charantia L.) Grown in rize ecological conditions.Turkish J. Agric. Nat. Sci.1:659-662.

[18] Savsatli, Y., Ozcan, A., Catal, M.I., Seyis, F., Akbulut, M. and AkyuzTurumtay, E. 2016. Trace elements in bitter melon (Momordica charantia L.) and their distribution in different plant parts. ARPN J. Agric. Biol. Sci. 11(11): 437-443.

[19] Unni P.N., Daniel G., Nair S.R. 1992. Effect of heavy metals on field crops I. Effect of lead on germination, growth and chlorophyll content in bitter gourd (Momordica charantia L.). Int. J. Environ. Stud. 41:115-119.

[20] USEPA (United States Environmental Protection Agency). 2000. Risk-based Concentration Table. United State Environmental Protection Agency, Washington, DC. 
[21] Verma, V.N. 2015. Chemical composition and quantitative elemental investigation of bitter melon. World Scientific News. WSN. 10: 8494.

[22] Wang, X., Sato, T., Xing, B. and Tao, S. 2005. Health risks of heavy metals to the general public in Tianjin, China via consumption of vegetables and fish. Sci. Tot.
Environ.350(1):28-37.

[23] Zhang, H., Huang, B., Dong, L., Hu, W., Akhtar, M.S. and Qu, M. 2017. Accumulation, sources and health risks of trace metals in elevated geochemical background soils used for greenhouse vegetable production in southwestern China. Ecotox. Environ. Saf. 137:233-239.

Citation: Chee Kong Yap, Aziran Yaacob, Mohd Hafiz Ibrahim, Rosimah Nulit, Chee Seng Leow. Heavy Metals in Bitter Gourd (Momordica charantia): Human Health Risk Assessment. ARC Journal of Nutrition and Growth. 2019;5(1):1-5. DOI: dx.doi.org/ 10.20431/2455-2550.0501001.

Copyright: (C) 2019 Authors. This is an open-access article distributed under the terms of the Creative Commons Attribution License, which permits unrestricted use, distribution, and reproduction in any medium, provided the original author and source are credited. 